\title{
O PROCESSO DE ESCOLHA DE UMA PROPRIEDADE PARA INSTALAÇÃO DE UMA URT EM ILPF: A EXPERIÊNCIA NO TERRITÓRIO DO RIBEIRÃO DO BOI ${ }^{1}$
}

\author{
William Fernandes Bernardo ${ }^{2}$ \\ Marcelo Dias Müller ${ }^{3}$ \\ Narliane de Melo Martins ${ }^{4}$ \\ Carlos Eugênio Martins ${ }^{5}$ \\ Pricila Estevão ${ }^{6}$
}

\section{RESUMO}

A pesquisa agropecuária produziu a partir da década de 1970 muitas tecnologias e conhecimentos que não chegaram a ser adequadamente utilizados pelos produtores rurais. Vários métodos de extensão rural foram criados para aumentar a adoção, por esse grupo, de tecnologias produzidas nas universidades e centros de pesquisa. Um desses métodos é a unidade de referência tecnológica (URT), que nesse caso é uma propriedade rural que utiliza determinada prática ou técnica inovadora. A escolha dessa propriedade, no entanto, não é simples, uma vez que há muitas URTs que não servem de espelho aos visitantes. O que o presente artigo discute são os requisitos para a escolha de uma propriedade para se constituir em uma URT com maiores chances de motivar os visitantes a utilizarem a técnica inovadora. Para isso, apresenta a experiência da escolha de uma URT na tecnologia de integração lavoura-pecuária-floresta (ILPF) no Território do Ribeirão do Boi, na região noroeste do Estado de Minas Gerais, Brasil. Na descrição da escolha da URT levam-se em conta as características do produtor, da tecnologia, da assistência técnica e da propriedade, sob uma análise crítica da ação extensionista nesse processo.

Palavras-chave: extensão rural, leite, unidade demonstrativa, unidade de referência tecnológica.

\footnotetext{
${ }^{1}$ O presente trabalho conta com o apoio da Empresa Brasileira de Pesquisa Agropecuária - Embrapa, que financia o projeto "Sistemas de integração lavoura-pecuária-floresta como alternativa para o desenvolvimento sustentável da bovinocultura leiteira em propriedades familiares em áreas montanhosas", sob a liderança do pesquisador da Embrapa Gado de Leite, Marcelo Dias Müller.

2 Técnico em agropecuária (EAFA). Graduado em agronomia (UFV). Mestrado em Extensão Rural (UFV). Licenciado e bacharel em Ciências Sociais (UFJF). Analista da Embrapa Gado de Leite. E-mail: williamfb2006@yahoo.com.br

${ }^{3}$ Graduado em Engenharia Florestal (UFV). Doutorado em Ciência Florestal (UFV). Pesquisador da Embrapa Gado de Leite. E-mail: marcelo.muller@embrapa.br

${ }^{4}$ Graduada Ciências Biológicas (UNILESTEMG). E-mail: narliane@ibio.org.br

${ }^{5}$ Graduado em Agronomia (UFV). Mestrado em Fitotecnia / Produção Vegetal (UFV) Doutorado em Solos e Nutrição de Plantas (UFV). Pesquisador da Embrapa Gado de Leite. E-mail: carlos.eugenio@embrapa.br

${ }^{6}$ Graduada em Comunicação Social (UEL). Mestrado em Extensão Rural (UFV). Analista da Embrapa Gado de Leite. E-mail: pricila.estevao@embrapa.br
} 


\title{
THE PROCESS OF CHOOSING A FARM FOR SETTING-UP A URT IN ILPF: THE EXPERIENCE ON THE RIBEIRÃO DO BOI TERRITORY
}

\begin{abstract}
Since 1970s, agricultural research produced many technologies and knowledge that were never properly used by farmers. Various extension methods are designed to increase the adoption, by that group, of technologies produced in universities and research centers. One of the methods is the technological reference unit (URT), a farm that uses a innovative practice or technique. The selection of this farm, however, is not simple, since there are many URTs that don't serves as a mirror to visitors. What this article discusses are the requirements for choosing a farm that could constitute an URT with great chances to stimulate visitors to use the innovative technique. To do so, that article presents the experience of URT selection in the technology 'integrated crop-livestock-forest system' (ICLFS or ILPF) at 'Território do Ribeirão do Boi', located in the northwest of Minas Gerais State, Brazil. In describing the selection of URTs it takes into account the characteristics of the farmer, technology, technical assistance and farm, in a critical analysis of the extension action in that process.
\end{abstract}

Keywords: demonstration unit, milk, rural extension, technological reference unit.

\section{INTRODUÇÃO}

Unidades de referência tecnológica (URT) são, na prática, propriedades rurais que são modelos ou referência para produtores vizinhos em uma ou mais práticas agropecuárias. Para se tornar modelo essas propriedades precisam utilizar determinadas práticas ou técnicas de forma eficaz que gerem resultados positivos em indicadores zootécnicos e/ou financeiros. Geralmente quem identifica essas propriedades como referência são os técnicos da assistência técnica e extensão rural que atuam no local. Há propriedades escolhidas para se tornar uma URT que não conseguem irradiar determinada tecnologia. O "fracasso", nesse caso, recai sobre a inadequação da tecnologia ou sobre alguma característica local que se desconhece.

Na montagem da URT usualmente busca-se uma tecnologia que esteja em um nível tecnológico adequado para a região e capaz de ser absorvida pelos produtores da vizinhança. Supondo que a tecnologia é adequada para determinados produtores, outras características da URT passam a ter relevância. O produtor rural, dono da propriedade, deve possuir algumas qualidades que o tornem referência na vizinhança.

Para tanto, são apresentadas para discussão as seguintes questões: i) como se seleciona uma URT? ii) quais critérios são importantes para a seleção de uma propriedade para se tornar uma referência aos vizinhos? iii) por que uma URT pode não ser eficaz em motivar pessoas a utilizarem a tecnologia que se pretende divulgar? iv) qual o papel do extensionista no contexto mercadológico da tecnologia na qual participa da divulgação por meio da URT? Essas perguntas serão discutidas nesse artigo por meio do caso da seleção de uma URT no território do Ribeirão do Boi, que abrange parcialmente os municípios de Entre Folhas, Vargem Alegre, Caratinga e Bom Jesus do Galho, em Minas Gerais. A tecnologia veiculada por meio da URT no território é a integração lavoura-pecuária-floresta (ILPF), um conjunto de 
técnicas que apresenta benefícios ambientais e de diversificação de renda, e que tem sido utilizado por pequenos produtores de leite de várias partes do Brasil.

\section{A PECUÁRIA DE LEITE E AS TECNOLOGIAS PARA A PEQUENA PRODUÇÃO}

No segmento do setor produtivo da cadeia do leite do Brasil há muitos resultados de pesquisa aplicada já disponíveis nos centros de pesquisa e universidades e, ao mesmo tempo, muita carência de tecnologias no campo (VILELA; BRESSAN; CUNHA, 2001). Esses autores acreditam que o setor pode ter sido vítima da manipulação populista recorrente na América Latina, uma vez que o produto leite foi pautado como item essencial para a dieta de faixas carentes da sociedade. Por esse motivo, o leite teria ficado submetido a controles de preço no mercado para evitar o aumento no custo de vida. Como consequência, os produtores de leite teriam assimilado os efeitos econômicos e sociais negativos dessa política.

Ao mesmo tempo em que o populismo controlava o preço do leite no Brasil, Silva (2003) enxerga outro processo que afetava agricultores de pequena escala. Para ele, o processo de modernização na agricultura fez com que os pequenos produtores ficassem sem condições de ter acesso às tecnologias capazes de impulsioná-los para maiores produções, produtividades e lucratividades pelo motivo de não terem capital para investir e porque as tecnologias disponíveis tinham alto custo, voltadas, portanto, à grande escala de produção (SILVA, 2003). A esse respeito, o autor explica que:

Quanto ao padrão tecnológico, orientado, basicamente, para uma expansão do complexo agroindustrial (a montante e a jusante da agricultura), mostra-se que ele não foi totalmente absorvido pelos pequenos produtores, conduzindo-os a um crescente diferencial de produtividade em relação às unidades que puderam se modernizar intensamente. $O$ fator limitante da modernização no setor camponês parece residir, fundamentalmente, na incompatibilidade entre escala mínima de produção requerida pelo novo padrão tecnológico e a insuficiência dos recursos produtivos e financeiros por parte daquele setor (SILVA, 2003, p. 138).

A mudança de perspectiva política no Brasil a partir dos anos 1990 recolocou holofotes nos produtores familiares, especialmente após a criação do Ministério do Desenvolvimento Agrário (MDA) em 25 de novembro de 19997. Como parte desse processo de mudanca de referencial institucional e ideológico do governo, em 31 de agosto de $2001^{8}$ ocorre a transferência para esse ministério das atribuições de atuar no desenvolvimento sustentável de agricultores familiares, ações que estavam na pasta do Ministério da Agricultura, Pecuária e Abastecimento (MAPA). Embora as recentes mudanças no cenário político nacional deixem fluidos os ancoradouros desse debate em termos institucionais, a questão da pequena produção continua na agenda da agropecuária nacional.

Com essa perspectiva, o trabalho da pesquisa e da extensão rural com agricultores familiares encontra-se na fase de resgate e reconstrução do tema sobre tecnologias adequadas para pequenos agricultores. Da mesma forma, muda a pesquisa agropecuária nacional que vinha atuando intensamente na perspectiva da

\footnotetext{
${ }^{7}$ Pela Medida Provisória (MP) nº 1.911-12.

${ }^{8}$ Pela MP oㅜ 2.216-37.
} 
modernização e passou a considerar também a nova conjuntura de demandas dos segmentos sociais.

\section{A INTEGRAÇÃO LAVOURA-PECUÁRIA-FLORESTA (ILPF)}

A integração lavoura-pecuária-floresta (ILPF) teve início nos anos 1980 com o "Sistema Barreirão", que visava a reforma e a melhoria das pastagens pelo aproveitamento do adubo residual de culturas anuais, como arroz e milho, cultivados em pastagens degradadas (YOKOYAMA et al., 1995). O "Sistema Barreirão" incorporou nos anos 1990 o plantio direto - passando a se chamar Sistema Santa Fé (ALVARENGA; GONTIJO NETO; CRUZ, 2009) - e nos anos 2000 foram incorporados os conceitos da agrossilvicultura (MACDICKEN; VERGARA, 1990; NAIR, 1993) com a introdução de árvores neste sistema, notadamente com o plantio de eucalipto em faixas estabelecidas em espaçamentos maiores para permitir a consorciação com pastagem, denominado ILPF.

A ILPF é uma tecnologia que congrega três componentes em uma mesma área: a lavoura (neste caso o milho), a pecuária (que soma o pasto e o gado de leite ou de corte) e a floresta. Os três componentes podem estar presentes na área em um mesmo momento (sistema agrossilvipastoril) ou em momentos subsequentes. Também permite as combinações IPF (silvipastoril), ILP (agropastoril) e ILF (silviagrícola). O governo federal incentiva o uso dessa tecnologia, conforme informa o site do Ministério da Agricultura, Pecuária e Abastecimento:

O pressuposto do sistema ILPF é de que o adubo residual da cultura anual (milho, por exemplo) irá proporcionar o aumento da produção por hectare subsequente do capim (e, consequentemente, da produção de leite e/ou carne) enquanto as árvores fornecem sombra e conforto térmico aos animais. Outra vantagem da integração de atividades é que, em uma mesma área, tem-se a produção animal (leite ou carne), produção florestal (madeira, frutos, etc.) e alimento (grãos, silagem, forragem), o que representa diversificação e aumento da renda ao produtor rural. A ILPF constitui-se, portanto, uma técnica de intensificação do uso da terra com o objetivo de recuperar pastagens degradadas e aumentar a renda do agricultor.

O Ministério da Agricultura firma convênios e acordos de cooperação técnica com órgãos, entidades e instituições públicas e privadas como estratégia para a capacitação de pessoal e como forma de incentivar a prática da ILPF entre os produtores rurais. O programa é desenvolvido pela Coordenação de Manejo Sustentável dos Sistemas Produtivos (CMSP), subordinada ao Departamento de Sistemas de Produção e Sustentabilidade (Depros), da Secretaria de Desenvolvimento Agropecuário e Cooperativismo (SDC) (BRASIL, 2014).

Para o MAPA, entre as vantagens da ILPF estão a recuperação de pastagens degradadas pela correção química do solo, a otimização e intensificação do uso do solo, a redução da vulnerabilidade econômica pela diversificação de atividades, a diminuição de pressão para a extração de madeiras de florestas naturais e o uso de práticas ambientais, como o plantio direto e a cobertura do solo para redução de erosão.

Conforme se pode observar, a ILPF é uma tecnologia que exige do produtor rural conhecimentos e/ou experiência nos três componentes (lavoura, pecuária de leite e/ou carne e floresta), além de noções de técnicas de proteção do solo. Ainda 
demanda o acesso a assistência técnica e a equipamentos para preparo do solo, plantio e tratos culturais.

\section{A URT COMO INSTRUMENTO DE EXTENSÃO RURAL, CAMPO DE IDEOLOGIAS E DE INTERESSES PARCIAIS}

Em termos de método, a extensão rural no Brasil tem sido alimentada nos últimos anos pelos referenciais da pedagogia e epistemologia de Jean Piaget, Paulo Freire e Pedro Demo (RUAS, 2006). Piaget acredita que o aprendizado segue um percurso que se inicia em um saber prévio (todos possuem um saber inicial a partir do qual construirá outro conhecimento), passa pelo contato com um novo saber que causa um desequilíbrio na forma de organização do pensamento, uma assimilação (a incorporação de novas experiências), uma acomodação (reorganização das estruturas mentais para a sedimentação dos novos conhecimentos) para chegar, por fim, a um saber reelaborado (RUAS, 2006; PALANGANA, 2001).

Paulo Freire possui princípios humanistas para propor ações dirigidas à autonomia, liberdade, dialogicidade e dialética entre aluno e professor (categoria que inclui o extensionista) em uma interação para resultar em uma construção coletiva e contínua de conhecimento (FREIRE, 1983). Pedro Demo defende uma ação educativa participativa e politizada para a formação de cidadãos críticos e autônomos que se valem do princípio de "aprender a aprender" para analisar, interpretar, sintetizar, formular e agir sobre a realidade (RUAS, 2006). Como método (da extensão rural), a URT pode ser incluída na definição geral de "conjunto de atividades sistemáticas e racionais que, com maior segurança e economia, permite alcançar o objetivo, traçando o caminho a ser seguido" (MARCONI; LAKATOS, 2008, p. 46). Na prática cooperativista, verifica-se que a participação cotidiana de produtores é de baixa qualidade, centrando-se a presença mais em eventos técnicos e menos em processos decisórios de gestão da cooperativa (TEIXEIRA; BERNARDO; MOREIRA, 2013). Como contraponto, Mattos e Santana (2014) verificaram ganhos de renda nos grupos de produtores de leite que estavam dispostos a aprender e a participar de associações e sindicatos.

A extensão rural vem utilizando as unidades demonstrativas como método de divulgação de práticas e tecnologias desde os primórdios das atividades extensionistas nos Estados Unidos no final do século XIX, sob a coordenação dos colégios agrícolas e das estações experimentais (FONSECA, 1985). Não há diferença significativa entre a unidade demonstrativa (UD) daquele período para a URT dos dias atuais. Pode-se aventar que houve mudanças em termos ideológicos entre os dois métodos uma vez que na URT dos dias atuais, em comparação à UD do passado, há espaço para discussão, crítica e até a negação da tecnologia. De fato, no passado a tecnologia era imposta para promover o desenvolvimento do país e o indivíduo era objeto da dominação política, econômica e social (FIGUEIREDO, 1989).

Os métodos de extensão rural, dos quais a UD fazia parte, se valiam de artifícios de convencimento, persuasão e marketing para mudar o comportamento do produtor e fazê-lo adotar determinada prática e assimilar as técnicas modernas da agropecuária (FONSECA, 1985; FIGUEIREDO, 1989). Coelho (2005, p. 61) entende "que tecnologia é a ciência e a técnica transformadas em mercadoria, em valor de troca. A socialização dessa forma de conhecimento fez-se pela difusão persuasiva para compra, e não pela socialização de habilidades criadoras".

Nos dias atuais a tecnologia ainda se impõe ao agricultor e ao técnico como uma mercadoria de fetiche e encantamento (qualidades do produto, segundo Marx) e esse objeto mágico tem o poder não apenas de resolver um problema agrícola ou 
pecuário, mas trazer mais renda e elevar o bem-estar do produtor e da sua família. Essa corrente de causa-efeito da tecnologia (solução técnica $x$ aumento de renda $x$ melhoria no bem-estar) não corresponde à realidade, embora técnicos de campo ainda acreditem nisso, uma falácia inerente da ideologia da modernidade. Esse falso silogismo possui uma conotação religiosa da tecnologia que a coloca no mundo do sagrado e, logo, no espaço do inquestionável. A esse respeito Hervieu-Léger (2008) afirma que a modernidade impõe um ritmo contínuo nas sociedades em que:

É preciso produzir sempre mais, conhecer sempre mais, comunicar-se sempre mais e sempre mais depressa. Essa lógica de antecipação, criada no âmago de uma cultura moderna dominada pela racionalidade científica e técnica, [é] um espaço sempre renovado para as produções imaginárias que esta racionalidade decompõe permanentemente (HERVIEU-LÉGER, 2008, p. 39).

E da mesma forma com que a ciência está imersa no campo do sagrado $^{9}$, a religião também busca elementos na racionalidade e no positivismo da ciência experimental, como é o caso do espiritismo kardecista (LEWGOY, 2008).

Em outra perspectiva, alguns profissionais que atuam no campo da agropecuária ainda veem a técnica como neutra, sempre direcionada ao bem-estar do produtor. Acreditam que aquele que produz a ciência está simplesmente a serviço do avanço tecnológico. Marx via esse tipo de pensamento como alienação, "a exteriorização do trabalhador só segundo um dos seus aspectos, a saber, a sua relação com os produtos do seu trabalho. Porém, a alienação não se mostra apenas no resultado, mas no ato da produção, dentro da atividade produtiva mesmo" (MARX; ENGELS, 1989, p. 152). A alienação se mostra pela falta de controle do trabalhador sobre seu trabalho e o produto de seu trabalho em um processo que ele próprio se torna mercadoria. A URT (assim como a UD) ainda é uma técnica que usa artifícios da comunicação e marketing com o objetivo de convencer produtores a adotarem uma determinada técnica, que foi previamente selecionada entre outras opções e recomendada por especialistas.

Minayo (2010) explica que o positivismo defende um "conhecimento objetivo, neutro, livre de juízo de valor, de implicações político-sociais” (p. 82) com a finalidade de trazer um conhecimento verdadeiro, mensurável e replicável. A autora argumenta que o positivismo surgiu com a revolução científica do iluminismo entre o final do século XVII e meados do século XVIII. A proposta era revolucionária, pois ia de encontro à influência e aos interesses da Igreja e das políticas dominantes à época. As ciências físicas e matemáticas forneceriam os instrumentos de quantificação precisos para oferecer resultados "livres de preconceitos". Hoje, no entanto, essa vertente positivista vem sendo substituída pelos métodos compreensivos, marxistas e de pensamento sistêmico.

Analisando a URT sob o prisma marxista do materialismo histórico, observa-se que o método pode ser uma vitrine que dá visibilidade a produtos da indústria, como máquinas, fertilizantes, defensivos agrícolas, material genético (determinadas plantas e certos animais - e não outros -, o que demonstra uma escolha). Se assim for, privilegia alguns produtos, fabricantes, distribuidores, revendedores e especialistas. A URT não seria, portanto, uma técnica neutra na esfera da extensão rural; emprega técnicas de diversas áreas do conhecimento

\footnotetext{
${ }^{9}$ Em 2006 um zootecnista de Pernambuco disse emocionadamente ao chegar na Embrapa: "de tantos artigos científicos que li dos pesquisadores aqui da Embrapa, eu estou me sentindo dentro a um templo [sagrado]".
} 
(ROGERS, 1974, p. 70) para mudar comportamentos e beneficiar alguns segmentos, produtos e serviços dentro da dinâmica do capitalismo. Os conceitos de homofilia e influência pessoal, que serão discutidos adiante, ilustram esses princípios, que estão imbricados no conceito, objetivo e eficácia da URT ${ }^{10}$.

Para não tratar a URT como simples vitrine do mercado e o técnico como vendedor de produtos, é preciso refletir sobre os insumos envolvidos na técnica (que podem levar o produtor à dependência e à perda da autonomia) e também sobre o método. Na visão atual da extensão rural, o método deve considerar o agricultor como indivíduo questionador e criador. Do mesmo modo, a tecnologia deve ser aberta e flexível o suficiente para permitir modificações e adaptações. O técnico também deve ser capaz de ouvir o produtor (assim como ouve o especialista) para criar uma técnica adaptada às condições da propriedade e do agricultor.

Freire (1983) indica aos extensionistas os caminhos do diálogo, da honestidade, da responsabilidade e da humildade para construir, junto com o agricultor, um conhecimento realmente significativo. Considerando que "o homem é um ser da 'praxis'; da ação e da reflexão" (FREIRE, 1983, p. 28), durante um processo educativo é necessário não apenas mostrar um conteúdo ou objeto novo, mas "revelar ou desvelar" (FREIRE, 1983, p. 28) o conhecimento. Assim agindo, o indivíduo se envolve em seu mundo como criador e criatura da realidade.

A seguir serão descritos e discutidos os passos e critérios que foram utilizados na escolha de uma propriedade rural a fim de se tornar uma URT. A tecnologia eleita para implantação é a ILPF e o local, o território do Ribeirão do Boi.

\section{METODOLOGIA}

A pesquisa com ILPF em andamento utiliza métodos das ciências biológicas e exatas para colher os dados do ambiente, tais como indicadores de qualidade do solo, de produção de forragens, de culturas anuais e de crescimento das árvores sob diversos tipos de arranjos espaciais, condições de solo, relevo e clima. Também emprega outros métodos para colher, sistematizar e compreender dados sociais a respeito da adoção da ILPF.

No aspecto da pesquisa social, o projeto em pauta faz entrevistas com produtores de leite que i) empregam a ILPF em suas propriedades, ii) conhecem mas não utilizam a ILPF e iii) utilizavam mas abandonaram o sistema ILPF. Por meio desses três grupos de produtores de leite busca-se conhecer quatro grandes grupos de conteúdos que poderiam explicar os fatores impulsores ou restritivos ao uso mais amplo da ILPF:

1) As características do produtor, como escolarização, condições econômicas e, especialmente, histórico profissional com lavoura, pecuária e componente florestal;

2) As características da propriedade, especialmente benfeitorias, equipamentos e gestão;

3) A disponibilidade e acesso a máquinas e implementos agrícolas para aluguel no município;

4) A existência e efetividade de assistência técnica capacitada no município para orientar na tecnologia ILPF.

\footnotetext{
${ }^{10}$ A extensão rural empregou elementos da psicologia e da antropologia (dentre outros campos da ciência) a seu favor para, por exemplo, classificar produtores em categorias de adotantes: inovadores, primeiros adotantes, maioria precoce, maioria tardia e retardatários. Segundo essa classificação, cada categoria de pessoas possuía determinadas características relacionadas à rapidez ou lentidão em mudar de comportamento para adotar uma tecnologia. Os retardatários (os últimos a adotar uma inovação), por exemplo, são mais velhos, tradicionais, semi-isolados, mais locais, que se veem não no futuro, mas no passado (ROGERS, 1974).
} 
A hipótese da pesquisa em adoção da ILPF é a de que os quatro fatores acima explicam suficientemente bem a aceitação ou rejeição da tecnologia. Para levantar os dados a campo foram aplicados questionários a produtores de leite com questões abertas e fechadas. Para obter uma explicação mais acurada da realidade, do ponto de vista dos produtores, a pesquisa levantou dados quantitativos, mas especialmente, informações qualitativas para análise. Minayo (2010) explica que:

O método qualitativo é o que se aplica ao estudo da história, das relações, das representações, das crenças, das percepções e das opiniões, produtos das interpretações que os humanos fazem a respeito de como vivem, constroem seus artefatos e a si mesmos, sentem e pensam (MINAYO, 2010, p. 57).

Os questionários utilizados na pesquisa em andamento sobre ILPF, com perguntas fechadas e abertas, buscaram captar dados quantitativos e qualitativos da propriedade, do contexto socioeconômico local, do produtor com sua história de vida e sua família. Acredita-se que essa composição metodológica é capaz de retratar as impressões dos produtores com relação à tecnologia e explicar as razões da adoção ou rejeição do uso da ILPF.

Especificamente para a escolha de uma propriedade para ser instalada a URT em ILPF no território do Ribeirão do Boi, o grupo participante da pesquisa utilizou o questionário como suporte para essa seleção, incluindo os aspectos qualitativos decorrentes do momento da entrevista. Para essa escolha foram empregados três critérios principais: a aptidão da propriedade para a implantação da ILPF em sua plenitude, as características intrínsecas do produtor e o seu interesse no uso da nova tecnologia. Uma vez conhecidos esses três grandes grupos de conhecimento e tendo a teoria como suporte, uma das quatro propriedades préselecionadas pelo IBIO foi indicada pelo grupo do IBIO e Embrapa para a instalação da URT. 
Figura 1 - Sequência de atividades até a instalação da URT no Território do Ribeirão do Boi

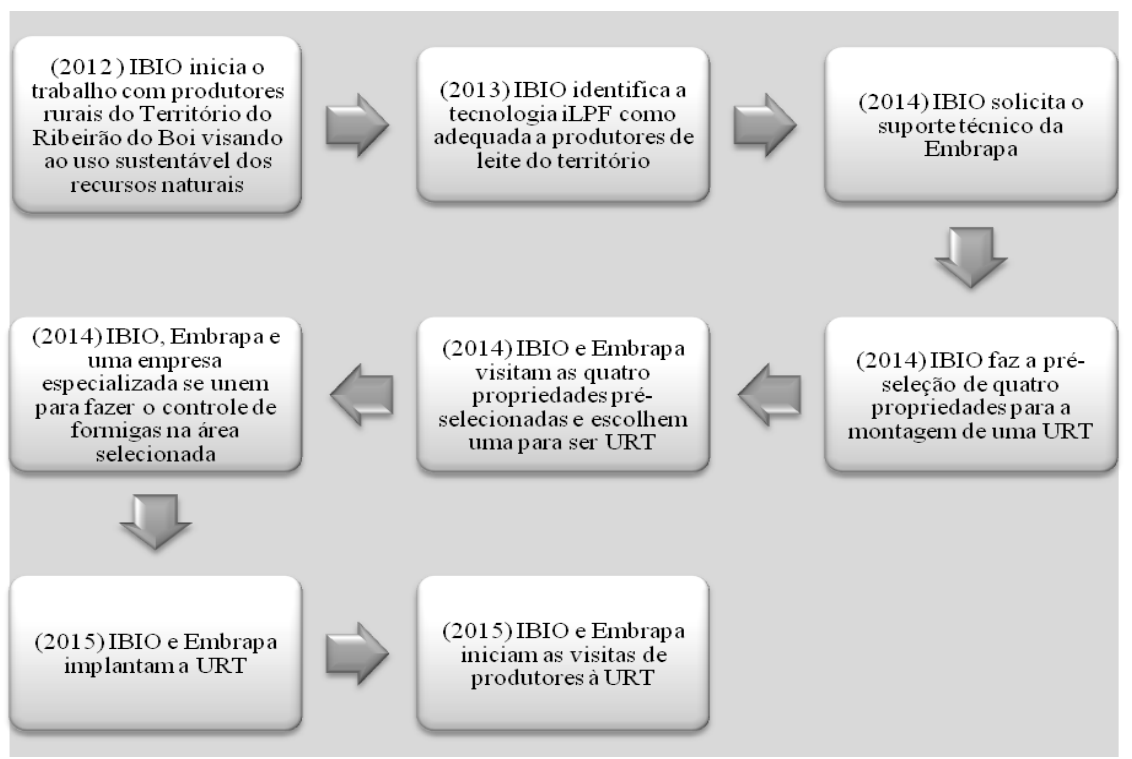

Fonte: os autores.

O presente artigo visa apresentar e discutir os critérios teóricos e metodológicos para a escolha de uma propriedade para se tornar uma URT, representado pela quinta etapa, em destaque, na Figura 1 acima.

Assim sendo, a seguir são apresentadas as atividades que precedem a seleção das propriedades (boxes 1 a 3 da Figura 1) para, em seguida, apresentar o resultado do trabalho: os critérios de seleção de quatro propriedades pelo IBIO (box 4 da Figura 1) e, com maior ênfase, os critérios para a seleção de uma propriedade mais adequada para a instalação da URT na tecnologia ILPF (box 5 da Figura 1). Na sequência há uma discussão sobre as características da propriedade escolhida como uma URT e a conclusão.

\section{O TRABALHO NO TERRITÓRIO DO RIBEIRÃO DO BOI E A ESCOLHA PELA TECNOLOGIA ILPF}

O território do Ribeirão do Boi é formado pelos municípios de Caratinga, Bom Jesus do Galho, Entre Folhas e Vargem Alegre, área que soma 35 mil hectares no centro-leste de Minas Gerais. Desde 2012 o Instituto Bioatlântica (IBIO) atua naquele território visando adequar o uso do solo e a aptidão regional para promover o uso sustentável dos recursos naturais. Para isso, realiza ações de monitoramento ambiental e faz contato com a comunidade local para conhecer o potencial produtivo do território. Dentre outras ações, realiza o Zoneamento Ambiental e Produtivo (ZAP).

Nos levantamentos que foram realizados com os habitantes do território pelo IBIO, a tecnologia ILPF surgiu como uma oportunidade de aproveitamento do mercado e da tradição existentes no local, como a produção de eucalipto, de leite e de milho, este cultivado principalmente para alimentação de animais domésticos 
(porcos e galinhas). Após a identificação dessa tecnologia pelo IBIO, foram feitos contatos com a Embrapa Gado de Leite e foi sugerida a montagem de uma URT no território. Em seguida, propriedades de leite foram visitadas pelos técnicos do IBIO para uma pré-seleção de locais adequados para a implantação da URT. E, posteriormente, quatro propriedades foram pré-selecionadas pelos técnicos após levantamento.

Paralelamente a essa ação do IBIO, a Embrapa Gado de Leite, no período de 2014 a 2016, conduz um projeto voltado para o estudo de sistemas de integração lavoura-pecuária-floresta em propriedades leiteiras familiares em áreas montanhosas para avaliar parâmetros técnicos da tecnologia de integração lavourapecuária-floresta (ILPF) e também sua disseminação e adoção por produtores de leite. Para isso, optou-se pela técnica de URT para que produtores pudessem conhecer de perto e ao vivo a ILPF e, assim, se motivassem a utilizá-la.

Após o contato entre IBIO e Embrapa Gado de Leite, foi agendada uma visita ao território Ribeirão do Boi para a escolha de uma propriedade em que seriam investidos esforços e recursos para a instalação da ILPF. Assim, as quatro propriedades de leite pré-selecionadas pelo IBIO foram visitadas por um grupo de empregados da Embrapa Gado de Leite e do IBIO com o objetivo de selecionar uma que seria viável à instalação de uma URT em ILPF.

\section{RESULTADOS}

\subsection{SELEÇÃO PRÉVIA DE QUATRO PROPRIEDADES PARA MONTAGEM DA URT EM ILPF}

Diante do desafio de pré-selecionar propriedades num território de $35 \mathrm{mil}$ hectares para a implantação de uma URT em ILPF, os técnicos do IBIO utilizaram como guia o "Manual Orientador para Implantação de Unidades de Referência Tecnológica de Integração Lavoura-Pecuária-Floresta-URT ILPF" (BALBINO et al., 2011). O Manual expõe aspectos importantes a serem considerados na identificação e escolha do produtor e respectiva propriedade e diz que produtor é peça-chave do processo de transferência de tecnologia objetivada com a implementação da URT em ILPF.

Os aspectos expostos no Manual são subdivididos em dois grupos: o primeiro trata de características desejáveis do produtor e o segundo, de características desejáveis da propriedade. Os aspectos a serem observados quanto ao produtor são: i) líder na região e formador de opinião; ii) disponibilidade de recursos para implantação e condução da URT em ILPF; iii) receptivo a mudanças e com características inovadoras; iv) produtor de fácil relacionamento interpessoal; v) predisposição e motivação necessárias à execução da URT em ILPF e sua manutenção no mesmo local por, no mínimo, quatro anos, ou um ciclo completo do sistema de produção que for mais longo, como, por exemplo, o componente florestal, que possibilite a realização das avaliações necessárias; vi) residência, preferencialmente, na propriedade (BALBINO et al., 2011).

No que tange à escolha da propriedade, o manual indica os seguintes aspectos: diagnóstico da propriedade (localização, área, clima, solo, sistemas de produção predominantes, nível tecnológico utilizado, infraestrutura existente, aptidão, principais limitações); localização da área onde será implantada a URT em ILPF deve ser em local de fácil acesso (em condições edafoclimáticas representativas da região e com infraestrutura mínima necessária a cada sistema de produção); topografia adequada ao cultivo e às práticas de conservação do solo (uniformidade física e química do solo); respeito ao tamanho mínimo e máximo para 
as áreas de cada cultura ou tecnologia que compõe a URT em ILPF, e que seja adequado em função do ciclo dos componentes envolvidos (lavoura, pecuária e floresta).

O primeiro passo da equipe do IBIO foi a identificação de produtores de leite por meio de busca no cadastro de produtores do projeto Território Sustentável do Ribeirão do Boi, que reúne as pessoas que participam de atividades realizadas pelo IBIO no território. Uma pré-seleção foi feita pelos técnicos para incluir no trabalho os produtores participativos e predispostos ao diálogo e à inovação. Para identificação de outras propriedades potenciais a se tornarem URT, foram contatadas secretarias municipais de agricultura e comércio local de produtos agropecuários. Foram visitadas, inicialmente, dezesseis propriedades e, dentre elas, quatro foram selecionadas para serem visitadas, em conjunto com a equipe da Embrapa, a fim de definir qual delas estaria mais apta a ser uma URT.

O número de propriedades selecionadas foi definido com atenção ao tempo disponível para as visitas. Os principais aspectos para o atendimento ao perfil desejado foram: i) propriedade representativa do local (área, conhecimento técnico, recursos financeiros e materiais); ii) facilidade de acesso pela qualidade das estradas; iii) interesse do proprietário em inovar e disposto a ser o primeiro a adotar novas tecnologias; iv) propriedade com situação fundiária regular; v) proprietário aparentemente com comprometimento e o cuidado necessário com a propriedade e seus sistemas produtivos.

As propriedades selecionadas atenderam aos seguintes aspectos: i) produtor líder na região e formador de opinião; ii) produtor receptivo a mudanças e com características inovadoras; iii) produtor de fácil relacionamento interpessoal; iv) produtor com predisposição e motivação necessárias à execução da URT em ILPF e sua manutenção; v) propriedade representativa quanto à topografia, área e nível tecnológico empregado.

Embora fosse desejável para o sucesso da implantação de uma URT que a propriedade/produtor possuísse um nível "mínimo" de tecnologia e recursos financeiros, selecionaram-se propriedades que tivessem esses recursos não na sua totalidade, a fim de garantir a representatividade no contexto local. Da mesma forma, para a escolha das propriedades para a montagem da URT levou-se em conta a escolha de áreas com montanhas, de modo a representar a característica típica da região.

\subsection{A SELEÇÃO DE UMA PROPRIEDADE, ENTRE QUATRO PRÉ- SELECIONADAS PELO IBIO, PARA A MONTAGEM DA URT}

A seguir serão descritas características das quatro propriedades préselecionadas pelo IBIO, entre as quais uma foi eleita para a montagem da URT. A descrição sucinta, a seguir, busca elencar aspectos que foram relevantes para a instalação da ILPF. Os critérios para a escolha, como se mostrará no tópico de discussão seguinte, consideraram aspectos técnicos, práticos e sociológicos. Os nomes dos produtores foram omitidos para não permitir a identificação e preservar a confidencialidade. Um dia após as visitas às propriedades foi realizado um evento na sede do município para divulgação da técnica de ILPF.

A primeira propriedade visitada possui 35 hectares e tem como proprietário um senhor que nasceu e foi criado naquele terreno rural e trabalhou na cidade vizinha, onde reside atualmente e se aposentou como professor. Possui o curso superior completo. A produção de leite é feita por um senhor que lida com o rebanho em regime de parceria com o proprietário e tem o controle do manejo do rebanho. $O$ proprietário tem muitas recordações de seu período de infância naquele ambiente. 
Apontou para uma pequena nascente e disse: "ali tinha peixe e hoje só tem esse brejo".

A grande motivação desse proprietário para a introdução da ILPF em sua área parece estar associada à reconstrução do patrimônio físico e cultural que está vivo em sua memória. Contou que seu filho não tinha interesse na área, mas recentemente mudou de opinião quando ingressou no curso de turismo e começou a enxergar o potencial turístico da região. A propriedade não tem disponibilidade de área para o plantio de milho (devido à alta declividade) em rotação com a pastagem e tem apenas um local para o cultivo de eucalipto. Com isso, seria possível implantar "apenas" o sistema silvipastoril (IPF). O produtor possui trator, arado e gradearadora. Para não deixar os equipamentos parados durante 0 ano pela falta de serviço na própria fazenda, o proprietário contrata um tratorista para fazer serviços para terceiros.

No momento da entrevista, o produtor estava sem tratorista e reclamava da falta de mão de obra disponível para o trabalho rural. Disse que contratava pessoas da cidade para o trabalho no campo e que quando planta milho e feijão, ele o faz em sistema de meação. Naquela data possuía 11 vacas no total, das quais quatro produziam leite. A produção era de 60 litros na época das águas e 30 litros na seca com o preço de $R \$ 1,00$ durante todo o ano, nas águas e na seca. O leite é resfriado na propriedade vizinha. A ordenha é manual e não se faz inseminação artificial. $O$ produtor esteve no evento sobre ILPF.

A segunda área avaliada tem como proprietário um senhor que vive da produção de leite, o qual está construindo um sistema de ordenha mecânica do tipo fosso para facilitar o trabalho. O produtor reclama de dores na coluna e acredita que o novo sistema de ordenha vai ajudá-lo a ganhar tempo e reduzir o peso do serviço. Sua propriedade tem 15 hectares e aluga pastos para colocar o gado "solteiro". Dessa forma, consegue manter em seu terreno apenas as vacas de leite em produção. Nasceu e foi criado na casa vizinha onde hoje pertence a outro morador e onde foi criado pela avó que o tratava muito mal, assim como a seus irmãos. Contou histórias tristes dos tempos de criança.

Esse produtor estudou até o $2^{\circ}$ ano do ensino fundamental. Planta milho para a despesa e já plantou eucalipto, "mas a formiga comeu". Na área de meia encosta em que poderia plantar eucalipto passa uma rede elétrica que impede o cultivo de eucalipto desta essência florestal. $\mathrm{Na}$ área de leito maior (baixada) pode ser cultivado o milho com a forrageira no formato ILP (ou agropastoril). O filho trabalha no comércio da cidade vizinha e, nas horas vagas, ajuda o pai na propriedade. O produtor contrata um trabalhador temporário para ajudá-lo nas tarefas diárias. Possui o total de 20 vacas e 15 estavam em lactação. Diz que retira diariamente 300 litros de leite na época das águas e 200 litros na época da seca, cujo preço é $R \$ 0,70$ e $R \$ 0,98$, respectivamente. Faz diariamente o teste da caneca de fundo preto (para detecção de mamite clínica) e o leite é resfriado na sua própria propriedade.

Esse proprietário não possui trator ou implementos e usa uma carroça com cavalo para o transporte de cana-de-açúcar e capim-elefante para as vacas. Disse que pretende iniciar a inseminação artificial das vacas. Seu filho tem planos de dar continuidade na propriedade, mas no dia da visita da Embrapa e IBIO o filho saiu da propriedade quando a equipe chegava e não retornou, demonstrando aparentemente desinteresse na implantação da ILPF. Em visita à sua propriedade o produtor disse: "eu deixo vocês plantarem aqui", apontando para a área de baixada. O grupo que visitava entendeu a frase como um gesto de educação do produtor em ceder a área para o trabalho mais do que um interesse em implantar uma nova tecnologia que o beneficiaria diretamente. Não se percebeu o envolvimento ou 0 
interesse na tecnologia ILPF. O produtor e seu filho não foram ao evento no qual a tecnologia foi apresentada e discutida em detalhe.

O produtor da terceira propriedade visitada, assim como o primeiro produtor, demonstrou grande apego emocional à propriedade onde nasceu e foi criado. Mostrou um engenho de cana-de-açúcar onde o pai fazia açúcar e rapadura. A propriedade tem uma vista maravilhosa de montanhas e possui um rio onde ele tomava banho quando era criança e onde se vê, do outro lado da margem, a escola rural onde estudou. Hoje, sua renda vem do trabalho temporário que tem com a prefeitura e da venda de bovinos de recria e engorda.

Esse proprietário concluiu o ensino médio e hoje é presidente da associação de produtores rurais da comunidade onde fica a propriedade. Reside na propriedade com sua família, sendo sua mãe aposentada. Morou por quatro anos nos Estados Unidos onde trabalhou para juntar dinheiro e retornar ao país. Reforçou que seu negócio hoje na propriedade é a recria e engorda de animais. A propriedade tem 20 hectares e 15 vacas de leite, sendo uma em lactação. Disse que tirava 60 litros na época das águas e 40 litros na seca, que eram vendidos a $R \$ 0,80$ e $R \$$ 1,00 , respectivamente. O leite é resfriado na propriedade vizinha. A ordenha é manual, não faz o teste da caneca de fundo preto e não faz inseminação artificial.

A área permite "apenas" a implantação de IPF (silvipastoril), uma vez que o terreno disponível tem declividade alta e impede o plantio de milho. Relatou que não possui trator ou implementos. Demonstrou interesse em implantar a ILPF em sua propriedade e em receber produtores rurais como visitantes. Esteve no evento de divulgação da ILPF no território.

A quarta propriedade tem 21 hectares, produz 33 litros na seca e 60 nas águas. O produtor tem a renda vinda da produção de leite, que processa em queijo, requeijão, manteiga e biscoitos para a venda em Ipatinga por meio de atravessador. Disse que costuma plantar tomate e tinha, no dia da visita, um plantio de cerca de 2 hectares de mandioca de mesa para a venda ao Ceasa (Centrais de Abastecimento de Minas Gerais), em Belo Horizonte. O proprietário estudou até a $5^{\underline{a}}$ série do ensino fundamental. A esposa e o filho mais velho trabalham nas atividades da propriedade.

Nesse local há 17 vacas no total, das quais sete estavam em lactação. Como a produção de leite da propriedade não segue in natura para o mercado, não importava a ele o preço do litro do leite no mercado e também não se faz necessário o tanque de refrigeração. A ordenha é manual, não faz o teste da caneca de fundo preto e não realiza a inseminação artificial nas vacas.

Identificou-se, também, que ali não havia trator ou implementos, mas um sistema de irrigação para uso na lavoura de tomate. Há um terreno de aproximadamente 2 hectares apto para a implantação da ILPF em todas as suas fases. Caminhando pelo terreno onde é possível a implantação da ILPF, observouse a ocorrência de inúmeros formigueiros, que na ocasião atacavam as plantas de mandioca. Registra-se que a sua esposa esteve presente no evento sobre ILPF, o que mostra o envolvimento familiar na proposta do projeto.

A análise conjunta das quatro propriedades mostrou que elas possuem em comum: a) áreas de montanha, típicas da região; b) não recebem assistência técnica; c) plantam milho para subsistência; d) não plantam eucalipto; e) não fazem anotações ou o gerenciamento técnico e financeiro da propriedade; f) não conhecem ou não empregam a ILPF em suas propriedades; g) o acesso é relativamente fácil a todas as propriedades, tanto na época da seca como das águas.

Embora o questionário semiestruturado não tivesse pergunta explícita sobre a história do produtor em relação à propriedade, apenas o quarto produtor não se manifestou espontaneamente sobre esse tema. $O$ discurso do primeiro e do terceiro 
produtor demonstravam o interesse no resgate de uma memória familiar e da infância, ao contrário do segundo produtor.

A quarta e última propriedade visitada foi a escolhida para a montagem da URT em ILPF. A eliminação das formigas cortadeiras se mostrava urgente e crucial para o sucesso da URT, uma vez que as plantas de eucalipto são muito atacadas, fator determinante para o sucesso na fase inicial de plantas jovens no campo. $O$ controle das formigas foi o primeiro e grande desafio técnico ao sucesso da tecnologia. A presença do grande número de formigueiros mostra a dificuldade ou incapacidade do produtor em lidar com esse problema em sua propriedade, apesar de sua experiência em trabalhar com a cultura do tomate, uma das mais complexas do campo da agronomia. A quantidade de formigueiros impressionou muito os técnicos da Embrapa Gado de Leite que caminharam pelo terreno onde será implantada a URT.

\section{DISCUSSÃO}

\subsection{OS CRITÉRIOS DE ESCOLHA DO LOCAL E DO PRODUTOR PARA IMPLANTAÇÃO DA URT: A OBSERVAÇÃO DE CAMPO E A TEORIA}

A unidade de referência tecnológica (URT) cria um ambiente no qual em um dia de campo os produtores vizinhos ouvem a explicação do técnico a respeito da inovação e também o depoimento do produtor rural que utiliza a tecnologia. Os produtores que visitam a propriedade têm a oportunidade de discutir entre si e avaliar em conjunto o que ouvem e veem na prática por ocasião da visita técnica à URT.

No caso do território do Ribeirão do Boi, os critérios para a escolha da propriedade para a implantação da URT foram:

a) a possibilidade de implantação da ILPF em todos os seus componentes: lavoura, pecuária (pastagem e vaca de leite) e floresta (eucalipto);

b) as características do produtor;

c) a motivação e interesse do produtor em utilizar a nova tecnologia recomendada pela equipe técnica.

Nos critérios acima se observa que há certas características inerentes à propriedade e outras próprias do produtor. Aquelas relativas à propriedade dizem respeito às condições naturais (topografia, água, fertilidade do solo, etc.) e de disponibilidade de máquinas e insumos (pequenos produtores da região não possuem, em geral, trator e implementos). A propriedade onde será instalada uma URT precisa espelhar as condições da vizinhança em termos de estrutura física e recursos disponíveis. Fica mais fácil aos produtores que visitam a URT ajustarem às suas condições a prática ou tecnologia que é aplicada em uma propriedade similar à sua.

Quanto ao produtor, o princípio é o mesmo. Uma URT necessita que o produtor tenha características similares da vizinhança. Rogers e Shoemaker (1974) empregam o termo homofilia para explicar esse efeito. Para eles, "homofilia é o grau de semelhança de pares de indivíduos em interação a respeito de alguns atributos, como opiniões, valores, educação posição social e coisas parecidas" (ROGERS; SHOEMAKER, 1974, p. 207). Os autores explicam que "as ideias se transferem com frequência máxima entre uma fonte e um receptor semelhantes e homófilos" ( $p$. 207), um dos princípios mais fundamentais da comunicação humana. Ao contrário, em uma interação heterofílica o receptor receberá informações que não coadunam com suas opiniões, que terão como resultado um incômodo psicológico (ROGERS; SHOEMAKER, 1974, p. 208-209). Os autores ressaltam ainda que "as diferenças 
em competência técnica, posição social, atitudes e opiniões contribuem para formar heterofilia em linguagem e significado que, por sua vez, produz mensagens incompreensíveis" (ROGERS; SHOEMAKER, 1974, p. 209).

A homofilia entre o extensionista e o produtor rural também é tema para discussão. Rogers e Shoemaker (1974) veem como um problema ético o fato de o extensionista estabelecer empatia por produtores com escolarização superior, maior posição social e renda. Dizem esses autores: "isso conduz a que se adotem as inovações primeiro entre essa clientela de elite, postergando aos que sofrem posições desvantajosas. Ao final de contas, o resultado se reduz a enriquecer mais os ricos" (ROGERS; SHOEMAKER, 1974, p. 237).

Em termos práticos, esses conceitos de Rogers e Shoemaker (1974) indicam que o produtor dono de uma propriedade que será URT deve ter características similares àqueles que se pretende chegar uma nova prática ou tecnologia. Em uma pesquisa feita com produtores de leite de Valença/RJ em 2012, um produtor relatava que muitos dias de campo haviam sido feitos em sua propriedade, mas reclamava que poucos produtores haviam adotado as técnicas que ele utilizava, nem mesmo seus parentes e vizinhos. Analisando a história de vida do produtor, é possível fazer algumas inferências sobre a baixa eficácia do processo.

Esse produtor de Valença/RJ havia deixado seu emprego em um banco para se dedicar exclusivamente à produção de leite. Enquanto transcorria a entrevista, ele disse que tinha feito um curso superior e que tinha bons contatos na cidade por conta de seu trabalho anterior no banco. Os referenciais de Rogers e Shoemaker (1974) possibilitam compreender que a experiência e o cosmopolitismo daquele produtor contribuíam para afastá-lo dos típicos produtores de leite da vizinhança. A heterofilia entre esse produtor e os produtores da localidade ajuda a explicar a baixa receptividade de suas palavras ante os vizinhos.

Em outra publicação, Rogers (1962) aponta quatro funções da influência pessoal no processo de adoção de uma inovação:

1) o conhecimento de uma inovação pode ser criado pela influência pessoal de outras pessoas; 2) uma vez formadas, opiniões sobre uma inovação são reforçadas pela interação com outras pessoas; 3) normas de inovação são geralmente comunicadas a membros de grupos via redes de influência interpessoais. Essas normas provavelmente são mais importantes nos estágios de avaliação onde os indivíduos decidem tentar ou não uma nova ideia; 4) a comparação da performance de uma inovação de ideias existentes podem ser comunicadas entre pares (ROGERS, 1962, p. 223-224).

Rogers (1962) defende que o processo de adoção compreende cinco fases sequenciais: primeiro contato, interesse, avaliação, teste e adoção. Para ele, a influência pessoal é muito importante na fase de teste, podendo inclusive substituir essa fase em casos em que a tecnologia não permite a divisibilidade para testes em pequena escala. Também diz que em situações de incerteza na tomada de decisão, o contato interpessoal permite a validação de opinião a respeito de uma inovação. Acredita-se que o método de URT permite ao visitante cumprir algumas das cinco etapas do processo de adoção descrito por Rogers (1962) para chegar a adotar uma inovação.

O produtor escolhido, dono da quarta propriedade visitada, tem sua renda exclusivamente proveniente da atividade, 0 que facilita 0 processo de reconhecimento por seus pares e exime a desconfiança de que a inovação possa ter 
sucesso em função de rendas externas do proprietário. O produtor não é cosmopolita, o que reduz a suspeita de que a implantação e os bons resultados da inovação decorrem dos relacionamentos interpessoais externos e privilegiados que o produtor poderia ter. O nível de escolaridade também está na média dos demais vizinhos, o que não deixa dúvidas quanto à capacidade dos demais em também adotarem a nova tecnologia.

Além disso, a escala de produção e os recursos disponíveis (trator e implementos) também não escapam ao padrão da região, mostrando que é possível utilizar a tecnologia naquele determinado nível socioeconômico, no caso o produtor familiar de leite. A experiência com o cultivo de tomate demonstra a capacidade de lidar com sistemas agrícolas mais complexos, como o emprego de calcário, adubo, irrigação, plantio e controle de pragas. Essa experiência, contudo, não foi suficiente para que o produtor obtivesse sucesso no controle de formigas que atacavam duramente o plantio comercial de mandioca em sua propriedade.

\section{CONCLUSÕES}

Durante muitos anos o Brasil foi receptor silencioso de tecnologias vindas dos "países de primeiro mundo". Para superar esse quadro, exemplo de alienação aos olhos de Marx, o extensionista precisa se localizar no contexto político, econômico e social do seu tempo. Da mesma forma, o produtor precisa ser leitor de sua realidade e autor de sua própria trajetória, conforme ensina Paulo Freire. A ciência, igualmente, não pode ser tratada como algo inquestionável e os resultados científicos não devem ser entregues cegamente a todos os usuários supondo serem suficientes e adequados para todas as situações. Também não há implicação direta entre as novas tecnologias e o bem-estar de agricultores e suas famílias, como descrevem inúmeros projetos de pesquisa e documentos de extensão rural do Brasil.

Nesse aspecto, os marcos referenciais e ideológicos atuais, que dão o norte às pesquisas e à extensão rural do País, precisam passar pelo critério científico básico: a dúvida, a crítica, ao teste de prova de Karl Popper. Como consequência desse processo, a proposição de novas tecnologias deve fazer parte de uma construção coletiva de conhecimentos a partir de populações críticas. É papel da ciência questionar seus próprios métodos e avaliar as mudanças e continuidades em termos de conceitos e processos.

A URT, como se discute aqui, tende a reproduzir um processo de apresentação mercadológica que trabalha como vitrine de alguns produtos comerciais em detrimento de outros. É preciso ter clareza disso: a ciência não é neutra. Ainda que não possa mudar essa situação, a estrutura atual da sociedade a transformação que seria o processo revolucionário de Marx -, o extensionista precisa entender sua posição no contexto e discutir esse processo com os produtores, conforme propostas de Pedro Demo e Paulo Freire. Com essa postura política de esclarecimento, o profissional de extensão rural pode melhor conduzir sua atuação e construir mecanismos de fortalecimento social e de cidadania junto aos produtores com os quais atua.

O presente artigo apresenta e discute o processo de escolha, entre quatro opções, de uma propriedade para instalação de uma URT (unidade de referência tecnológica). No caso do projeto no território do Ribeirão do Boi, o tema foi ILPF (integração lavoura-pecuária-floresta), uma tecnologia apoiada fortemente pelo governo brasileiro nos dias atuais com base principalmente em ganhos ambientais. A ILPF é apropriada a pequenos agricultores, inclusive de regiões montanhosas, na recuperação de pastagens degradadas e diversificação da produção e renda. $O$ 
texto discute o método da URT, os critérios da escolha da propriedade e as reflexões a respeito da ação extensionista no contexto social, político e econômico.

A ILPF se constituiu, portanto, como pano de fundo para as discussões sobre as escolhas feitas pelos profissionais que trabalham no setor agropecuário e suas implicações. A seleção de uma propriedade rural como URT leva em consideração principalmente os aspectos socioculturais e econômicos do produtor, a característica da propriedade, o acesso a máquinas e a assistência técnica qualificada. O sucesso da URT como fonte irradiadora de práticas e de tecnologias para produtores depende, portanto, da análise detalhada desses quatro fatores.

O trabalho de campo foi realizado no Território do Ribeirão do Boi, que compreende os municípios de Entre Folhas, Vargem Alegre, Caratinga e Bom Jesus do Galho, localizados no nordeste de Minas Gerais. A propriedade escolhida para a implantação da URT tinha como proprietário um produtor que vive exclusivamente da atividade leiteira e está na média dos padrões locais em termos de produção agropecuária, tamanho de área, capital social, escolarização e perfil socioeconômico. Esses elementos são importantes para uma URT na medida em que os produtores visitantes precisam enxergar o modelo proposto como viável para suas condições. Rogers e Shoemaker (1974) defendem que a semelhança entre fonte e receptor de uma comunicação, chamada de "homofilia", é fundamental para uma máxima eficiência no processo comunicativo.

O texto reporta o passo a passo da implantação de uma URT desde a concepção da ideia, pelo IBIO, a busca de parceiro técnico, a Embrapa, e a escolha de uma propriedade para a instalação da URT na tecnologia selecionada. Aqui se faz a reflexão sociopolítica do uso da técnica de URT pelo viés da ação extensionista e a escolha do local para vitrine de determinadas práticas e tecnologias, seleção sempre parcial e não neutra.

\section{REFERÊNCIAS}

ALVARENGA, R. C.; GONTIJO NETO, M. M.; CRUZ, J. C. Sistema Barreirão. In: Disponível Cultivo do Sorgo. 5. ed. Sete Lagoas: Embrapa Milho e Sorgo, 2009.

$<$ http:/www.cnpms embrapa.br/publicacoes/milho 5 ed/integracao.htm >. Acesso em: 13 set. 2016 .

BALBINO, L. C. et al. Manual orientador para implantação de unidades de referência tecnológica de integração lavoura-pecuária-floresta URT iLPF. Planaltina, DF: Embrapa Cerrados, 2011. p. 48. (Embrapa Cerrados. Documentos, 303)

BRASIL. Ministério da Agricultura, Pecuária e Abastecimento. Integração, lavoura, pecuária e floresta. Brasília, DF, [201-]. Disponível em: <http://www.agricultura.gov.br/desenvolvimento-sustentavel/integracao-lavourapecuaria-silvicultura>. Acesso em: 13 set. 2016.

COELHO, F. M. G. A arte das orientações técnicas no campo: concepções e métodos. Viçosa, MG: UFV, 2005. p. 139.

FIGUEIREDO, V. Produção social da tecnologia. São Paulo: EPU, 1989. p. 54.

FONSECA, M. T. L. A extensão rural no Brasil: um projeto educativo para o capital. São Paulo: Loyola, 1985. p. 192. 
FREIRE, P. Extensão ou comunicação? 8. ed. Rio de Janeiro: Paz e Terra, 1983. p. 93.

HERVIEU-LÉGER, D. O peregrino e o convertido: a religião em movimento. Petrópolis: Vozes, 2008. p. 238.

LEWGOY, B. A transnacionalização do espiritismo kardecista brasileiro: uma discussão inicial. Religião e Sociedade, v. 28, n. 1, p. 84-104, jul. 2008. Disponível

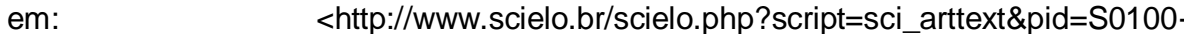
$85872008000100005 \&$ Ing=en\&nrm=iso >. Acesso em: 13 set. 2016.

MACDICKEN, K. G.; VERGARA, N. T. Agroforestry, classification and management. New York: John Wiley \& Sons, 1990. p. 382.

MARCONI, M. A.; LAKATOS, E. M. Métodos científicos. In: Metodologia científica. 5. ed. São Paulo: Atlas, 2008. p. 44-98.

MARX, K.; ENGELS, F. K. Marx: Trabalho alienado e superação positiva da autoalienação humana. In: FERNANDES, F. (Org.) Marx e Engels: história. 3. ed. São Paulo: Ática, 1989. p. 146-181.

MATTOS, C. A. C.; SANTANA, A. C. As contribuições da pecuária leiteira para os agricultores familiares: um estudo no Sudeste do Estado do Pará. Extensão Rural, Santa Maria, v. 21, n. 1, jan./mar. 2014. Disponível em: <http://periodicos.ufsm.br/extensaorural/article/view/7780/pdf>. Acesso em: 13 set. 2016.

MINAYO, M. C. S. O desafio do conhecimento: pesquisa qualitativa em saúde. 12. ed. São Paulo: Hucitec, 2010. p. 405.

NAIR, P. K. An introduction to agroforestry. Dordrecht: Kluwer Academic Publishers, 1993. p. 499.

PALANGANA, I. C. A concepção de Piaget. In: Desenvolvimento e aprendizagem em Piaget e Vygotsky. São Paulo: Summus, 2001. p. 13-31.

ROGERS, E. M. Diffusion of innovations. New York: Free Press of Glencoe; London: Macmillan New York, 1962. p. 367.

ROGERS, E. M.; SHOEMAKER, F. F. La comunicación de innovaciones: un enfoque transcultural. México: Herrero Hermanos Sucesores, 1974. p. 385.

RUAS, E. D.; et al. Metodologia participativa de extensão rural para o desenvolvimento sustentável - Mexpar. Belo Horizonte: Emater-MG, 2006. p. 132.

SILVA, J. G. Tecnologia e agricultura familiar. 2. ed. Porto Alegre: UFRGS, 2003. p. 238.

TEIXEIRA, S. R.; BERNARDO, W. F.; MOREIRA, M. S. P. O que pensam os produtores e jovens filhos de produtores de leite sobre a atividade leiteira. Extensão Rural, Santa Maria, v. 20, n. 1, jan./abr. 2013. Disponível em: 
<http://periodicos.ufsm.br/extensaorural/article/view/8589/5212>. Acesso em: 13 set. 2016.

VILELA, D.; BRESSAN, M.; CUNHA, A. S. Cadeia de lácteos: restrições ao seu desenvolvimento. Brasília, DF: MCT/CNPq; Juiz de Fora: Embrapa Gado de Leite, 2001. p. 484.

YOKOYAMA, L. P.; et al. Sistema Barreirão: análise de custo/benefício e necessidade de máquinas e implementos agrícolas. Goiânia: EMBRAPA-CNPAF, 1995. p. 31. (EMBRAPA-CNPAF. Documentos, 56). 